FINAL REPORT

\title{
The Flux and Recycling of Bioactive Substances in the Surface Sediments of the Deep Basins Off Southern California
}

\author{
Project \# DE-FG09-88ER60627, originally DE-FG05-ER85-60334
}

\author{
Richard A. Jahnke - Principal Investigator
}

\section{March 1992}

\section{DISCLAIMER}

\begin{abstract}
This report was prepared as an account of work sponsored by an agency of the United States Government. Neither the Unired States Governmerit nor any agency thireof, nor any of their employees, makes any warranty, express or implied, or assurnes any legal liability or monsonsbility for the accuracy, completeness, or usefulness of any information, apparatus, product, or process disclosed, or represents that its use would not infringe privately owned rights. Reference terein to any specific commercial product, process, or service by trade name, trademark, manufacturer, or otherwise does nut necessarily constitute or imply its endorsernent, racommendation, or favoring by the United States Government or any agency thereof. The views and opinions of authors expressed herein do not necessarily state or reflest those of the United States Government or anly agency thereof.
\end{abstract}

\section{MASTER}




\section{INTRODUCTION}

The overall goals of the project were to investigate the processes responsible for the recycling of particulate material reaching the sea foor in the California Borderland Basins. As initially proposed, we planned an investigation of sediment diagenesis in several of the California Borderland Basins. The particular issues that were to be the focus of the study were:

1. What proportion of the detrital materials that sink out of the photic zone are recycled in the sediments?

2. Are the differences observed between sampling locations explainable by differences in bottom water chemistry and/or particulate input using present models?

3. What is the diffusive exchange of trace metals across the sedimen/water interface and what mechanisms control their mobilization in surface sediments and pore waters?

4. Is the formation of authigenic minerals (such as iron and manganese oxides or sulfide and apatites) within the surface sediments important to the pore water chemistry and, hence, benthic fluxes?

5. Do the respiratory rates calculated through geochemical evidence correlate with those estimated via biological assays?

Once initial funding decisions were made by DOE, the Principal Investigators met to coordinate their individual efforts into a comprehensive program (the California Basin Study $; \mathrm{CaBS}$ ). It was decided to focus the study within a single basin, Santa Monica Basin, rather than study several basins. This decision eliminated the comparative aspects of my original proposed project (question \#2 above) and at the same time provided an uniquely strong coordinated effort in which to study sediment processes. In the following, I summarize the major accomplishments of research conducted as part of the CaBS project.

\section{Organic Matter Diagenesis and Benthic Fluxes}

We have used pore water gradients and in situ benthic flux chamber measurements to assess the total and down-core variations in the organic carbon remineralization rate. In addition to standard pore water extractions, we developed techniques to extract pore water samples at $2 \mathrm{~mm}$ sampling intervals, greatly improving our assessment of near-surface vertical gradients. In addition, much emphasis was placed on directly measuring the exchange of chemicals between the bottom waters and sediment pore waters via in situ benthic flux chamber incubations. The latter were performed with the MANOP bottom lander, and in later expeditions, the Benthic Experimental Chamber Instrument (BECI). Both of these devices were developed with NSF support. Results from these measurements were used to assess the following aspects of seafloor organic matter diagenesis.

\section{Influence of bottom water oxygen on organic carbon burial efficiency}

By comparing the amount of organic carbon buried in the sediments with the total amount deposited (calculated as the amount buried plus the amount recycled), the accumulation efficiency was calculated. For Santa Monica Basin, 43\% of the organic carbon reaching the sea floor is permanently buried. We have compared this value with those calculated for other California Borderland Basins which differ in bottom water oxygen content. The results suggest that during the early stages of organic matter diagenesis (the portion best represented 
by benthic flux measurements) there is little influence of the bottom water oxygen content on the overall accumulation efficiency. These results have immediate potential implications for future studies of carbon (including antiropogenic carbon) removal from the ocean and for the interpretation of organic carbon variations in the sedimentological record (discussed in ref. $5 \& 2)$.

\section{Constraining the reactivity of deposited organic matter}

By assessing pore water gradients and total sea floor fluxes, we estimate the contribution of specific sediment intervals to the total sediment decomposition rate. Because the sediments in the basin are laminated, we can also accurately estimate the age of each sediment layer.

The results demonstrate that organic matter diagenesis could unambiguously not be described by a single degradation rate constant. At a minimum, sea floor diagenesis requires two types of organic matter of very different reactivities. We estimate that the most labile fraction decomposes with a half-life of $<6.5$ years while the more resistant fraction has a halflife of 1700 years (discussed in ref. 5).

\section{Reaction Stoichiometery}

Because of the low bottom water oxygen concentrations, organic matter remineralization in Santa Monica Basin sedirnents below the upper few millimeters is dominated by sulfate reduction reactions. Previous studies of these processes that have been performed primarily in east coast near-shore sediments such as Cape Lookout Bight and Long Island Sound have demonstrated that approximately two moles of carbon dioxide are produced for every mole of sulfate utilized.

In the Santa Monica Basin, pore water distribution indicate a near 1:1 relationship between sulfate ronsumed and carbon dioxide released. These results suggest that there is still an unknown process that may affect the oxidation state of the reacting organic carbon or of the produced sulfur species to account for this different relationship. These differences, if applicable to other sulfate reducing sediments, may alter significantly estimates of organic carbon cycling based on sulfate reduction rates (discussed in ref. 5).

In addition to the studies of the benthic processes themselves, the benthic carbon budget that was derived for the Santa Monica Dasin has been used to assess the role of ocean margin regions in the oceanic carbon cycle.

\section{Export of organic matter off the Santa Monica continental shelf}

Because that basin should trap organic materials transported from the adjacent continental shelf, the carbon budget for the deep basin was used to assess whether a significant portion of the organic matter produced on the shelf was advected offshore. Because of the high rates of primary production on continental shelves, even a transport of $5.10 \%$ would be detectable in the deep basin. The results suggested that export of organic material from the adjacent continental shelf was not necessary to balance the deep basin carbon budget (discussed in ref. 4).

\section{Assessing carbon fluxes in ocean basins}

We have also examined the role of ocean margins in the basin-wide organic carbon cycle. We have examined this in two papers in which we compiled benthic flux results for the 
Atlantic and Pacific Ocean Basins. These results have very strongly suggested that margin systems contribute significantly to the input of organic matter to the deep ocean (discussed in ref. 3). These compilations have also demonstrated that the overall pattern of benthic fluxes follow, very closely, the distribution pattern of primary productivity in the overlying surface waters. This implies, that benthic respiration in the deep ocean must be support by particulate fluxes and not by the transport of dissolved organic caroon from the surface waters. This sets a upper limit as to the importance of DOC transport in the marine organic carbon cycle. By integrating these results, we have also been able to demonstrate that organic carbon fluxes into the deep ocean are dominated by input in the lower latitudes. In fact, the results indicate that $>70 \%$ of the carbon input to the deep waters occurs within $30^{\circ}$ of the equator (discussed in ref. 6).

\section{Trace Metal Geochemistry}

We have studied the geochemistry, pore water mobility, and benthic exchange of trace metals in the California basins. This work has been accomplished through pore water studies by Dr. Tim Shaw. To constrain the processes that control the trace elements in the pore waters, Dr. Shaw combined the results from Santa Monica Basin with those from other California Borderland Basins of different redox and depositional character. The results represent the Ph. D. Thesis work of Dr. Shaw (Shaw, T. J. (1988) The Early Diagenesis of Transition Metals in Nearshore Sediments. Ph. D. Thesis, University of California, San Diego, 164p) (discussed in ref. 9).

\section{Biological Metabolic Rates}

Because recycling is mediated by biological metabolic processes, there should be a general correspondence between respiration rates inferred from microbial studies of growth and incorporation efficiency and sea floor oxidant and carbon fluxes. The CaBS program represented an unique opportunity to assess the relative consistency of these measurements.

During the CaBS project, we modified techniques to permit fine-scale (1-2 mm) sampling and incubation of surface microbial communities. Utilizing these techniques, we were able to demonstrate that most of the biomass and metabolic activity was restricted to the uppermost $0.5 \mathrm{~cm}$ of the deep basin sediments. This extreme concentration of the bionass and biological activity at the sediment surface may be the result of the absence of sediment mixing (the sediments are laminated) and the lack of benthic boundary layer predators due to low oxygen conditions). Furthermore, these studies demonstrated that the real errors involved in the microbial measurements are too large for these measurements to be useful in establishing benthic carbon budgets by themselves. In order for the two type of measurements to be internally consistent, the benthic microorganisms must efficiently incorporate detrital organic carbon (generally incorporating $>70 \%$ of the carbon ingested and respiring only 30\%) (discussed in ref. 1,2,7). This has lead to further studies in my' lab 1. new techniques for assessing grow'th and respiration (especially in anaerobic systems) 2. Fisld studies of benthic microbial ates off Peru, 3.further investigations of this sort in oxic systems off the east coast as part cf my continuing DOE research. 
Summary of students trained or who benefited through DOE support.

T. J. Shaw, Ph.D. 1988; Scripps Institution of Oceanography

C. Rabouille, Ph.D. 1990; L'Universite de Paris 7

Current Post-Doc, Dr. Ellery Ingall, studying the forms of sedimentary phosphorus in margin sediments.

\section{Summary of Publications to Date Acknowledging DOE Support}

1. Craven, D. B., R. A. Jahnke, A. F. Carlucci (1986) Fine-scale vertical distributions of microbial biomass and activity in California Borderland sediments. Deep-Seal Res. 33:379-390.

2. Smith, Jr., K. L., A. F. Carlucci, R. A. Jahnke and D. B. Craven (1987) Organic carbon mineralization in the Santa Catalina Basin: benthic boundary layer metabolism. DeepSea Res. 34:185-211.

3. Jahnke, R. A. and G. A. Jackson (1987) Role of sea floor organisms in oxygen consumption in the deep North Pacific Ocean. 329:621-623.

4. Jackson, G. A., F. Azam, A. F. Carlucci, R. W. Eppley, P. M. Williams, B. Finney, C-.A. Huh, L. F. Small, D. S. Gorsline, B. Hickey, R. A. Jahnke, I. R. Kaplan, M. I. Venkatesan, M. R. Landry, and K. M. Wong (1989) Elemental cycling and fluxes off Southern California. Trans. Am. Geophys. Union 70:146-149, 154-155.

5. Jahnke, R. A. (1990) Early diagenesis and recycling of biogenic debris at the seafloor, Santa Monica Basin, California. J. Mar. Res. 48:413-436.

6. Jahnke, R. A. and G. A. Jackson (1992) The spatial distribution of sea floor oxygen consumption in the Atlantic and Pacific Oceans. in Deep-Sea Food Chains and the Global Carbon Cycle, G. T. Rowe and V. Pariente, eds. NATO Workshop, Kluwer Academic Publishers.

7. Craven, D. B. and Jahnke, R. A. (in press) Microbial utilization and turnover of organic carbon in Santa Monica Basin sediments. Prog. Oceanogr. Ser. (attached)

8. Carlucci, A. F., D. B. Craven and D. M. Wolgast (1991) Microbial populations in surface films and subsurface waters: amino acid metabolism and growth. Mar. Biol. 108: 329339

9. Shaw, T. J., J. M. Gieskes and R. A. Jahnke (1990) Early diagenesis in differing depositional environments: The response of transition metals in pore water. Geochim. Cosmochim. Acta 54:1233-1246. 

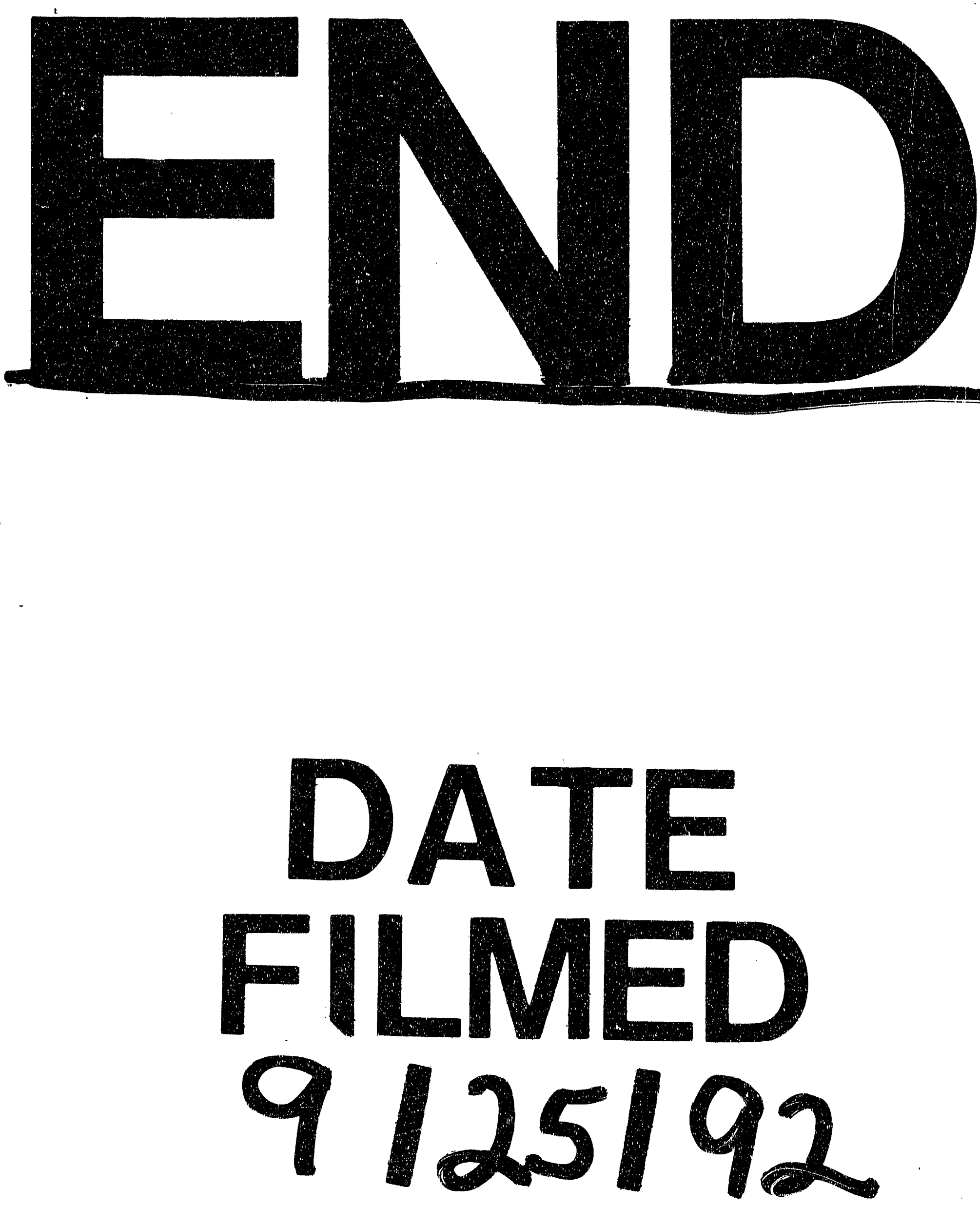


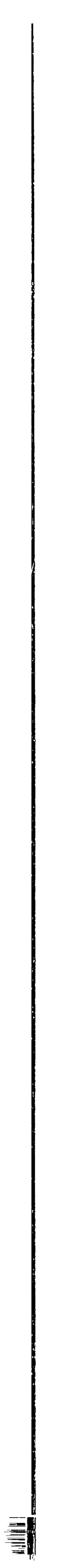

